\title{
Glycine receptor modulating antibody predicting treatable stiff-person spectrum disorders
}

Shannon R. Hinson, PhD, A. Sebastian Lopez-Chiriboga, MD, James H. Bower, MD, Joseph Y. Matsumoto, MD, Anhar Hassan, MBBCh, Eati Basal, PhD, Vanda A. Lennon, MD, PhD, Sean J. Pittock, MD, and Andrew McKeon, MD

Neurol Neuroimmunol Neuroinflamm March 2018;5:e438. doi:10.1212/NXI.0000000000000438

\section{Abstract}

\section{Background}

Glycine receptor alpha-1 subunit (GlyRa1)-immunoglobulin G ( $\operatorname{IgG}$ ) is diagnostic of stiff-person syndrome (SPS) spectrum but has been reported detectable in other neurologic diseases for which significance is less certain.

\section{Methods}

To assess GlyRa1-IgGs as biomarkers of SPS spectrum among patients and controls, specimens were tested using cell-based assays (binding $\left[4^{\circ} \mathrm{C}\right]$ and modulating [antigen endocytosing, $\left.37^{\circ} \mathrm{C}\right]$ ). Medical records of seropositive patients were reviewed.

\section{Results}

GlyRa1-IgG (binding antibody) was detected in 21 of 247 patients with suspected SPS spectrum ( $8.5 \%$ ) and in 8 of 190 healthy subject sera (4\%) but not CSF. Among 21 seropositive patients, 20 had confirmed SPS spectrum clinically, but 1 was later determined to have a functional neurologic disorder. Sera from 9 patients with SPS spectrum, but not 7 controls, nor the functional patient, caused GlyR $\alpha 1$ modulation (100\% specificity). SPS spectrum phenotypes included progressive encephalomyelitis with rigidity and myoclonus (PERM) (8), classic SPS (5), stiff limb (5), stiff trunk (1), and isolated exaggerated startle (hyperekplexia, 1). Neuropsychiatric symptoms present in 12 patients (60\%) were anxiety (11), depression (6), and delirium (3). Anxiety was particularly severe in 3 patients with PERM. Objective improvements in SPS neurologic symptoms were recorded in 16 of 18 patients who received first-line immunotherapy ( $89 \%, 9 / 10$ treated with corticosteroids, $8 / 10$ treated with IVIg, 3/4 treated with plasma exchange, and 1 treated with rituximab). Treatment-sparing maintenance strategies were successful in 4 of 7 patients (rituximab [2/3], azathioprine [1/1], and mycophenolate $[1 / 3])$.

\section{Conclusions}

GlyRa1-modulating antibody improves diagnostic specificity for immunologically treatable SPS spectrum disorders.

\section{Classification of evidence}

This study provides Class IV evidence that GlyR $a 1$-modulating antibody accurately identifies patients with treatable SPS spectrum disorders.

\author{
Correspondence \\ Dr. McKeon \\ mckeon.andrew@mayo.edu
}




\section{Glossary}

AChR $=$ acetylcholine receptor; FITC $=$ fluorescein isothiocyanate; DAPI $=$ 4,, 6 -diamidino-2-phenylindole; GAD65 = glutamic acid decarboxylase 65-kDa isoform; GlyRa1 = glycine receptor alpha-1 subunit; IgG = immunoglobulin G; PBS = phosphatebuffered saline; PERM = progressive encephalomyelitis with rigidity and myoclonus; SLE = systemic lupus erythematous; SPS $=$ stiff-person syndrome.

Immunoglobulin G (IgG) autoantibody targeting the glycine receptor alpha-1 subunit (GlyRa1-IgG) is diagnostic and presumably a cause of stiff-person syndrome (SPS) spectrum disorders. ${ }^{1-4}$ Unified by clinical and electrophysiologic evidence of CNS hyperexcitability, SPS spectrum disorders include classical SPS, focal disorders (e.g., stiff-limb syndrome), and progressive encephalomyelitis with rigidity and myoclonus (PERM), which is generalized and severe. Immunotherapy response occurs more commonly among GlyRa1-IgG-positive SPS spectrum patients than among patients with SPS in general (usually glutamic acid decarboxylase $65-\mathrm{kDa}$ isoform [GAD65] antibody-positive). ${ }^{3}$ However, GlyR $\alpha 1$-IgG has been reported in other neurologic disorders, including optic neuritis and demyelinating diseases, for which significance of the antibody finding is uncertain. ${ }^{1,3,5}$ Further insights into the significance of GlyR $\alpha 1-\operatorname{IgG}$ may be ascertained by evaluation of antibody functions, such as modulation. ${ }^{1}$ This is temperature-dependent antigen endocytosis occurring as a consequence of intermolecular crosslinking by bivalent IgG. Other examples of neurologic diseases in which antigenic modulation has been shown to have pathogenic significance include myasthenia gravis, NMDA receptor encephalitis, and neuromyelitis optica. ${ }^{6-8}$ Here, we report our laboratory testing experience for GlyRal binding and modulating IgGs among physician-referred patients, as well as controls used for the purpose of validating our GlyRal binding assay in a clinical laboratory setting.

\section{Methods}

\section{Patients and controls}

Patients (247) had suspected SPS spectrum diagnoses (made on the basis of neurologic and electrophysiologic findings), and testing for GlyRa1-IgG was requested, 2013-2016. None were previously reported. ${ }^{3,4}$ Control specimens (240) were acquired for the purpose of validating our assay for clinical use as required by the College of American Pathologists: (1) serum from 190 patients (140 healthy subjects [adults, 100; children, 40], 25 patients with polyclonal hypergammaglobulinemia, and 25 patients with systemic lupus erythematous [SLE] or Sjögren syndrome without neurologic complications) and (2) CSF from 50 patients (30 adults with normal pressure hydrocephalus and 20 children with hereditary neurologic disorders).

\section{GlyRa1-IgG cell-binding assay}

HEK293 cells were grown on poly-D-lysine-coated, multiwell chamber slides (Corning). Half were transfected with a plasmid encoding, untagged, human GlyRal subunit. ${ }^{1}$ After 24 hours, the slides were exposed to patient or control serum (1:5) or CSF (undiluted) at $4^{\circ} \mathrm{C}$ for 30 minutes. After washing with cold phosphate-buffered saline (PBS), cells were incubated on ice for 30 minutes with a fluorescein isothiocyanate (FITC)-conjugated goat anti-human IgG antibody (1:100; Southern Biotechnology Associates, Inc., Birmingham, AL). Cells were washed with PBS and fixed in $4 \%$ paraformaldehyde for 15 minutes at room temperature. After washing and chamber removal from slides, cells were mounted in ProLong ${ }^{\circledR}$ Gold Antifade mounting media with 4',6-diamidino-2-phenylindole (DAPI) (Molecular Probes). GlyRa1-IgG positivity was determined by visualization of robust membranous staining of transfected, but not nontransfected, cells by indirect immunofluorescence. Scoring (positive or negative) was performed by 2 readers blinded to clinical diagnosis and each other's interpretation. All positive results were confirmed on a repeat assay by 2 independent readers.

\section{GlyRa1-IgG modulating assay}

Twenty-four hours after transient transfection, patient or healthy control serum (heat inactivated $\left[56^{\circ} \mathrm{C}\right]$ to deplete complement) was added to the GlyR $\alpha 1$-transfected cells and incubated for an additional 4 hours at $37^{\circ} \mathrm{C}$. ${ }^{1,7}$ Slides were then washed twice at $4^{\circ} \mathrm{C}$. The positive control serum was diluted in $20 \%$ normal goat serum and added to the cells (on ice). After 30 minutes, cells were washed in cold PBS, and goat anti-human IgG-FITC secondary antibody (Southern Biotechnology Associates, Inc.) was added and incubated for 30 minutes. Cells were washed and fixed in $4 \%$ paraformaldehyde for 15 minutes. After further washing, cells were mounted in Prolong Gold plus DAPI (Molecular Probes) and imaged (Zeiss LSM780 confocal microscope). ImageJ software was used for quantitation.

\section{Results}

\section{GlyRa1-IgG binding antibodies as biomarkers of SPS spectrum}

GlyRa1-IgG (binding antibody, figure 1) was detected in serum, CSF, or both in 21 of 247 patients tested (8.5\%), 16 of whom were evaluated neurologically at Mayo Clinic and 5 of whom were evaluated elsewhere. Twenty of 21 patients were confirmed to have an SPS spectrum disorder. The remaining patient, patient 21 , a 45 -year-old woman, was initially suspected to have PERM because of spells of diffuse body shaking. She had a final diagnosis of a functional movement 

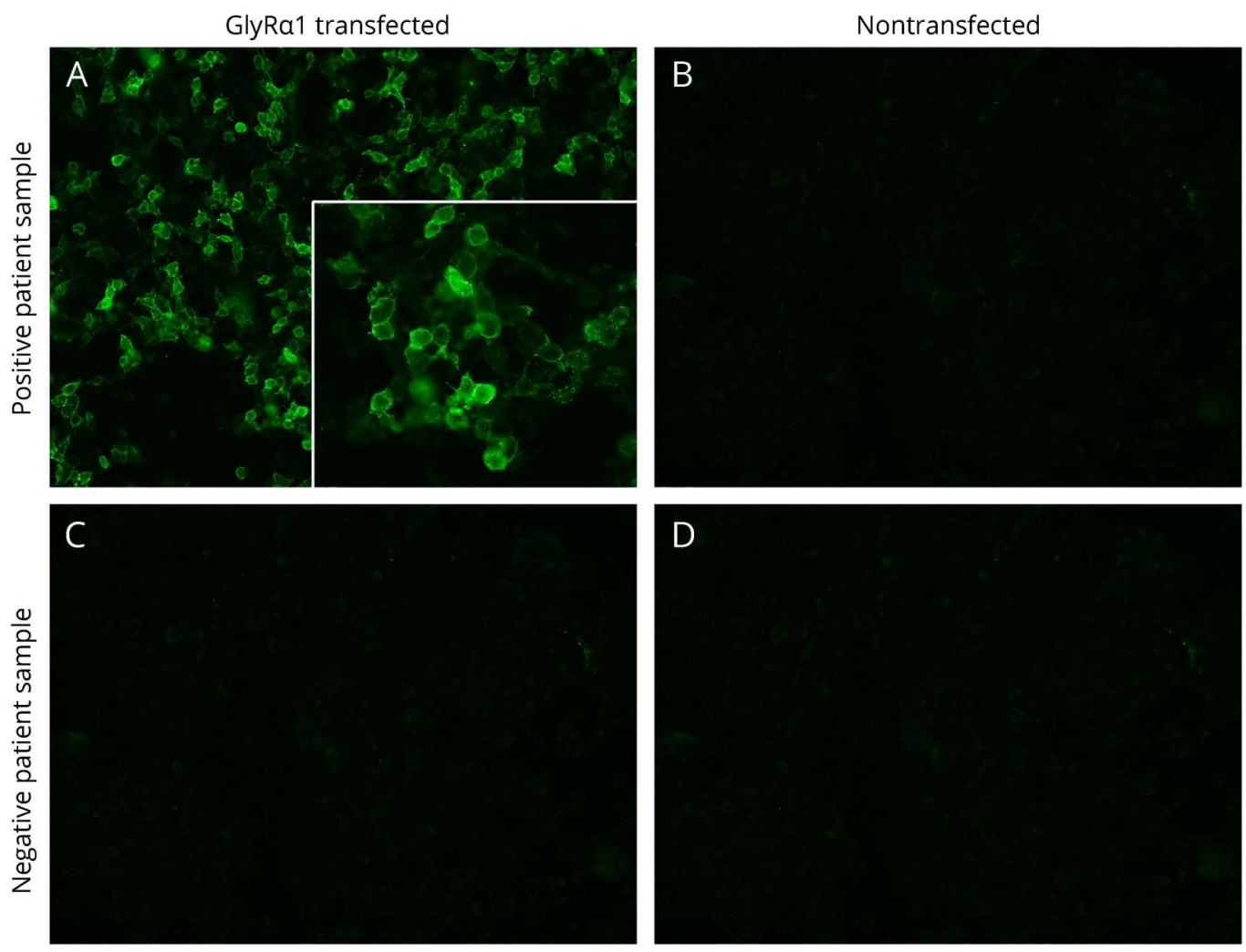

Bound IgG in reactive serum is detected by fluorescein-conjugated goat anti-human IgG (green, A) and is nonreactive with nontransfected cells (B). IgG in the sera of healthy controls is nonreactive with both cell types (C and D). Images captured at $\times 20$. GlyRa1 = glycine receptor alpha-1 subunit.

disorder after evaluation by a movement disorder specialist. The patient remitted completely from her functional disorder with behavioral rehabilitative training ${ }^{9}$ and was excluded from our clinical report below.

None of the 50 CSF controls, but 8 of 190 serum controls, were GlyRa1-IgG positive (4.0\%; 4 healthy adults [4.0\%], 1 healthy child $[2.5 \%], 2$ patients with polyclonal hypergammaglobulinemia [8.0\%], and 1 patient with SLE [4.0\%]). They all produced robust membranous staining of GlyRa1transfected, but not nontransfected, cells, indistinguishable from patients.

\section{GlyRa1-IgG modulating antibody improves specificity}

We investigated whether serum from patients with SPS spectrum disorders, the functional patient, and healthy subjects induced antigen endocytosis (modulation) when applied to live GlyRa1-expressing cells. On evaluating a patient with SPS spectrum (patient 5, figure 2A), cells incubated on ice had bound IgG on the cell surface while the cells incubated at $37^{\circ} \mathrm{C}$ had very little bound human IgG. Heat maps (intensity images) demonstrate the difference in fluorescence intensity between $4^{\circ} \mathrm{C}$ and $37^{\circ} \mathrm{C}$, suggesting that GlyR $\alpha 1$ is internalized and lost from the plasma membrane by bound patient GlyR $\alpha 1-\operatorname{IgG}$ at $37^{\circ} \mathrm{C}$. To test our hypothesis that testing for
GlyRa1-modulating antibody might improve specificity, sera from patients with definite SPS spectrum ( 9 of 20 had sufficient specimen available), healthy subjects (7; 5 GlyRa1-IgG negative and 2 GlyRa1-IgG falsely positive), and the functional patient (GlyRa1-IgG falsely positive) were assessed. After serum exposure, cells were immunostained live on ice with GlyRa1-IgG-positive patient's serum. Both seronegative (figure 2B.b) and seropositive (figure 2B.c) sera from healthy subjects did not internalize GlyRal protein. By contrast, cells exposed to serum from the patients (exemplified by patient 5 , figure 2B.a) induced loss of GlyR $\alpha 1$ from the plasma membrane. Immunofluorescence quantitation of an untreated GlyR $\alpha 1$-IgG-positive serum, the 7 healthy subjects, the 1 functional patient, and 9 patients with SPS spectrum supported that only sera from patients with SPS spectrum disorders-induced GlyRal loss from the plasma membrane (100\% specificity, figure 2C).

\section{Clinical findings among patients with SPS spectrum}

Twenty patients had organic neurologic SPS spectrum disorders, 11 were male (table). The median age at symptom onset was 45 years (range, 10-70). The median follow-up period was 11 months (range, 1-120 months). GlyRa1-IgG (binding antibody) was detected in the serum of 19 patients, 3 of whom (of 12 tested) also had positivity in CSF. 
Figure 2 Serums of patients with stiff-person syndrome spectrum disorders containing GlyRa1-Binding IgG specifically induces internalization of GlyRa1 from transfected HEK293 cell surfaces

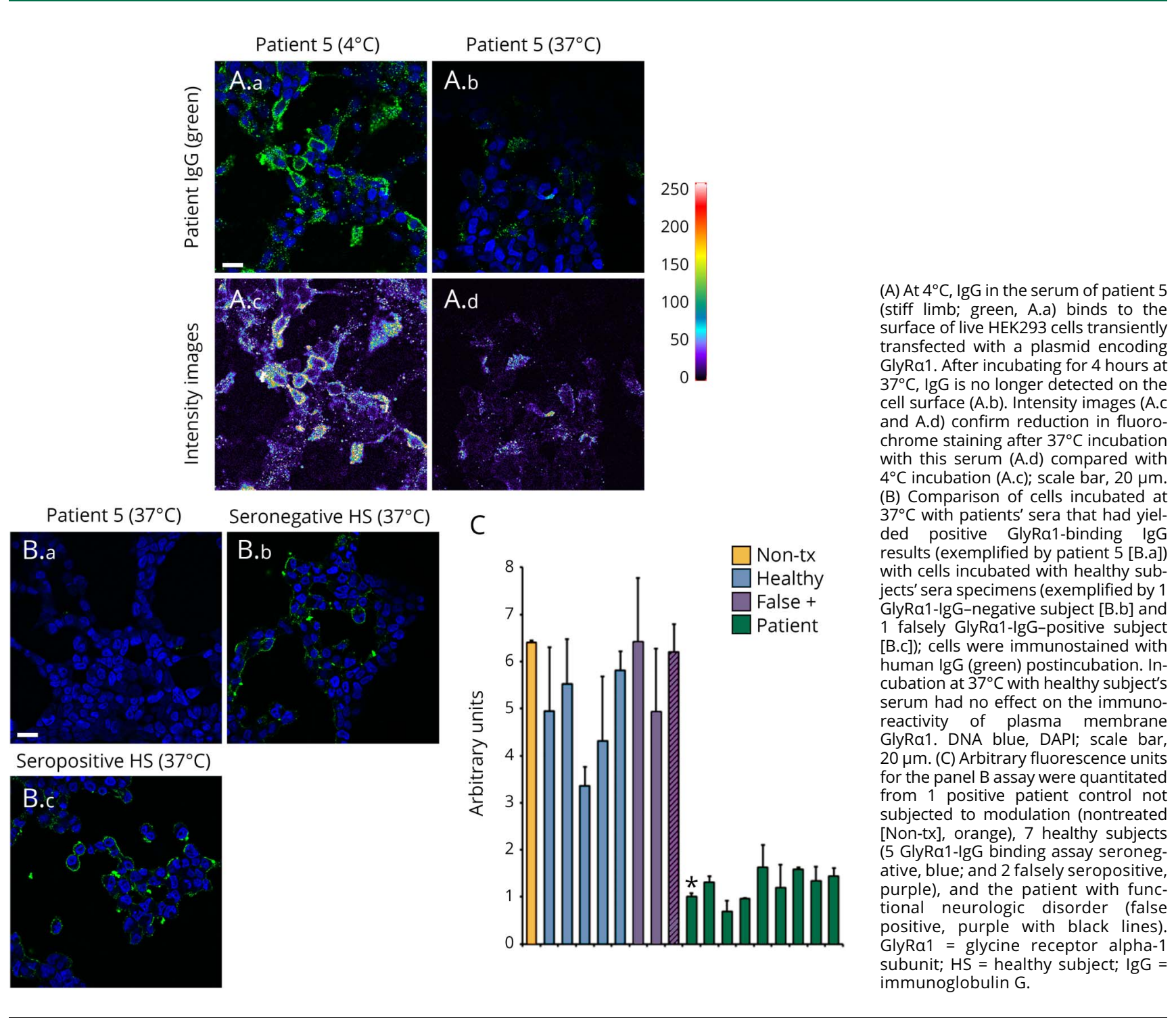

GlyRa1-IgG was detected in CSF alone in 1 additional PERM patient who had dysautonomia (ileus, hypotension, and bradycardia) and died of his illness.

Neurologic phenotypes included the following (table): PERM (8), classic SPS (5), stiff limb (5), stiff trunk (1), and isolated exaggerated startle (hyperekplexia, 1). Limb stiffness (16, [lower extremities, all; upper extremities, 7]) was the most common finding. Gait abnormalities reported in 13 patients included frequent falls (10) and gait ataxia (7). Brainstem symptoms included diplopia (4), dysphagia (3), and dysarthria (3). Neuropsychiatric symptoms present in 12 patients (60\%) were as follows: anxiety (11), depression (6), and delirium (3). Anxiety was particularly severe in 3 patients with PERM (1 required inpatient psychiatric admission for treatment).
Four patients had a neoplasm detected (20\%). Neurologic symptoms preceded neoplasia diagnosis (thymoma, 2; Hodgkin lymphoma) in 3 patients and occurred at ovarian adenocarcinoma relapse in 1 . Five patients $(25 \%)$ had coexisting autoimmunity (Hashimoto thyroiditis, 2; ulcerative colitis, 1; Addison disease, 1; and vitiligo, 1). GAD65 antibody coexisted in the sera of 6 patients (30\%): median value, $60.2 \mathrm{nmol} / \mathrm{L}$; range, 0.04-3,861 (normal range, 0.00-0.02 $\mathrm{nmol} / \mathrm{L}), 1$ of whom was also positive in CSF $(25.8 \mathrm{nmol} / \mathrm{L})$. None were dipeptidyl peptidase 6 (DPPX)-IgG positive.

CSF data were abnormal in 6 of 14 patients (43\%): protein elevation (6), white cell count elevation (2), and CSFexclusive oligoclonal bands (4). MRI of head was abnormal in 2 of 17 patients (12\%), both of whom had PERM. The abnormalities were as follows: diffuse $\mathrm{T} 2$ hyperintensity of 
Table Findings, treatment responses, and outcomes among 20 patients with GlyRa1-IgG-positive stiff-person spectrum

\begin{tabular}{|c|c|c|c|c|c|c|c|c|c|c|}
\hline $\begin{array}{l}\text { Patient } \\
\text { no.I } \\
\text { Sex/ } \\
\text { Age }\end{array}$ & $\begin{array}{l}\text { Neurologic } \\
\text { phenotype/ } \\
\text { psychiatric } \\
\text { phenotype }^{a}\end{array}$ & $\begin{array}{l}\text { Serum } \\
\text { IgG } \\
\text { antibody } \\
\text { findings }\end{array}$ & $\begin{array}{l}\text { CSF } \\
\text { antibody } \\
\text { findings }\end{array}$ & $\begin{array}{l}\text { Movement } \\
\text { laboratory } \\
\text { evaluation }\end{array}$ & $\begin{array}{l}\text { Steroids } \\
\text { given } \\
\text { (improved) }\end{array}$ & $\begin{array}{l}\text { IVIg given } \\
\text { (improved) }\end{array}$ & $\begin{array}{l}\text { PLEX given } \\
\text { (improved) }\end{array}$ & $\begin{array}{l}\text { Infusion- } \\
\text { sparing } \\
\text { drug } \\
\text { (success) }\end{array}$ & $\begin{array}{l}\text { mRS: } \\
\text { Pre/ } \\
\text { Post }\end{array}$ & $\begin{array}{l}\text { Follow- } \\
\text { up } \\
\text { (mo) }\end{array}$ \\
\hline $1 / \mathrm{M} / 62$ & PERM & GlyRa1 & NA & NA & $+($ Yes $)$ & ND & ND & - & $3 / 1$ & 4 \\
\hline $2 / M / 31$ & $\begin{array}{l}\text { SPS/anxiety- } \\
\text { depression }\end{array}$ & GlyRa1 & NA & $\begin{array}{l}\text { Exaggerated } \\
\text { acoustic } \\
\text { startle }\end{array}$ & $+($ Yes $)$ & $+($ Yes $)$ & $+(\mathrm{No})$ & - & $4 / 2$ & 120 \\
\hline $3 / F / 44$ & SPS/anxiety & $\begin{array}{l}\text { GlyRa1/ } \\
\text { GAD65 } \\
\text { (544 } \\
\text { nmol/L) }\end{array}$ & Negative & $\begin{array}{l}\text { Exaggerated } \\
\text { acoustic } \\
\text { startle }\end{array}$ & ND & ND & ND & - & $3 / N A$ & 1 \\
\hline $4 / M / 37$ & $\begin{array}{l}\text { Stiff limb/ } \\
\text { anxiety }\end{array}$ & $\begin{array}{l}\text { GlyRa1/ } \\
\text { GAD65 } \\
\text { (419 } \\
\text { nmol/L) }\end{array}$ & GlyRa1 & NA & $+($ Yes $)$ & ND & ND & Aza (Yes) & $4 / 1$ & 11 \\
\hline $5 / M / 53$ & $\begin{array}{l}\text { Stiff limb/ } \\
\text { anxiety }\end{array}$ & GlyRa1 & Negative & $\begin{array}{l}\text { Exaggerated } \\
\text { acoustic } \\
\text { startle/ } \\
\text { exaggerated } \\
\text { exteroceptive } \\
\text { response }\end{array}$ & ND & ND & ND & - & $3 / 1^{b}$ & 27 \\
\hline $6 / F / 33$ & $\begin{array}{l}\text { PERM/anxiety- } \\
\text { depression }\end{array}$ & GlyRa1 & Negative & NA & $+(\mathrm{No})$ & ND & ND & - & $3 / 6^{c}$ & 5 \\
\hline $7 / F / 21$ & $\begin{array}{l}\text { Stiff limb/ } \\
\text { depression }\end{array}$ & GlyRa1 & Negative & $\begin{array}{l}\text { Exaggerated } \\
\text { acoustic } \\
\text { startle/ } \\
\text { exaggerated } \\
\text { exteroceptive } \\
\text { response }\end{array}$ & ND & $+(\mathrm{No})$ & ND & - & $4 / 4$ & 10 \\
\hline $8 / F / 29$ & PERM & GlyRa1 & GlyRa1 & NA & $+($ Yes $)$ & ND & ND & - & $3 / 2$ & 12 \\
\hline 9/F/47 & $\begin{array}{l}\text { SPS/anxiety- } \\
\text { depression }\end{array}$ & GlyRa1 & Negative & Normal $^{d}$ & ND & $+($ Yes $)$ & ND & $\begin{array}{l}\text { Myco } \\
\text { (Yes) }\end{array}$ & $4 / 1$ & 25 \\
\hline $\begin{array}{l}10 / \mathrm{M} / \\
46\end{array}$ & Hyperekplexia & GlyRa1 & Negative & $\begin{array}{l}\text { Exaggerated } \\
\text { acoustic } \\
\text { startle }\end{array}$ & ND & $+($ Yes $)$ & ND & - & $3 / 1$ & 1 \\
\hline 11/F/16 & $\begin{array}{l}\text { SPS/anxiety- } \\
\text { depression }\end{array}$ & $\begin{array}{l}\text { GlyRa1/ } \\
\text { GAD65 } \\
\text { (3,861 } \\
\text { nmol/L) }\end{array}$ & $\begin{array}{l}\text { Negative/ } \\
\text { GAD65 } \\
\text { (25.9 } \\
\text { nmol/L) }\end{array}$ & NA & ND & $+($ Yes $)$ & ND & - & $4 / 1$ & 1 \\
\hline 12/F/12 & $\begin{array}{l}\text { SPS/anxiety- } \\
\text { depression }\end{array}$ & GlyRa1 & Negative & $\begin{array}{l}\text { Exaggerated } \\
\text { acoustic } \\
\text { startle/ } \\
\text { exaggerated } \\
\text { exteroceptive } \\
\text { response }\end{array}$ & ND & $+($ Yes $)$ & $+($ Yes $)$ & $\begin{array}{l}\text { Ritux, } \\
\text { (Yes) }\end{array}$ & $3 / 1$ & 20 \\
\hline $\begin{array}{l}13 / \mathrm{M} / \\
60\end{array}$ & PERM & GlyRa1 & Negative & Normal $^{d}$ & ND & $+($ Yes $)$ & ND & $\begin{array}{l}\text { Myco } \\
\text { (No) }\end{array}$ & $3 / 1$ & 22 \\
\hline $14 / F / 60$ & $\begin{array}{l}\text { PERM/anxiety- } \\
\text { depression }\end{array}$ & GlyRa1 & NA & NA & ND & ND & $+($ Yes $)$ & - & $3 / 2$ & 1 \\
\hline $\begin{array}{l}15 / \mathrm{M} / \\
70\end{array}$ & PERM & $\begin{array}{l}\text { GlyRa1/ } \\
\text { GAD65 } \\
(0.30 \\
\text { nmol/L) }\end{array}$ & NA & NA & $+($ Yes $)$ & $+($ Yes $)$ & ND & - & $3 / 2$ & 2 \\
\hline $\begin{array}{l}16 / \mathrm{M} / \\
50\end{array}$ & Stiff limb & GlyRa1 & GlyRa1 & NA & $+($ Yes $)$ & ND & ND & - & $2 / 0$ & 38 \\
\hline $\begin{array}{l}17 / M / \\
66\end{array}$ & $\begin{array}{l}\text { PERM- } \\
\text { dysautonomia/ } \\
\text { anxiety- } \\
\text { depression }\end{array}$ & $\begin{array}{l}\text { Negative/ } \\
\text { GAD65 } \\
(0.06 \\
\text { nmol/L) }\end{array}$ & GlyRa1 & Normal $^{d}$ & $+($ Yes $)$ & $+($ Yes) & $+(Y e s)^{e}$ & $\begin{array}{l}\text { Myco } \\
\text { (No) }\end{array}$ & $3 / 6^{c}$ & 47 \\
\hline
\end{tabular}


Table Findings, treatment responses, and outcomes among 20 patients with GlyRa1-lgG-positive stiff-person spectrum (continued)

\begin{tabular}{|c|c|c|c|c|c|c|c|c|c|c|}
\hline $\begin{array}{l}\text { Patient } \\
\text { no./ } \\
\text { Sex/ } \\
\text { Age }\end{array}$ & $\begin{array}{l}\text { Neurologic } \\
\text { phenotype/ } \\
\text { psychiatric } \\
\text { phenotype }^{a}\end{array}$ & $\begin{array}{l}\text { Serum } \\
\text { IgG } \\
\text { antibody } \\
\text { findings }\end{array}$ & $\begin{array}{l}\text { CSF } \\
\text { antibody } \\
\text { findings }\end{array}$ & $\begin{array}{l}\text { Movement } \\
\text { laboratory } \\
\text { evaluation }\end{array}$ & $\begin{array}{l}\text { Steroids } \\
\text { given } \\
\text { (improved) }\end{array}$ & $\begin{array}{l}\text { IVIg given } \\
\text { (improved) }\end{array}$ & $\begin{array}{l}\text { PLEX given } \\
\text { (improved) }\end{array}$ & $\begin{array}{l}\text { Infusion- } \\
\text { sparing } \\
\text { drug } \\
\text { (success) }\end{array}$ & $\begin{array}{l}\text { mRS: } \\
\text { Pre/ } \\
\text { Post }\end{array}$ & $\begin{array}{l}\text { Follow- } \\
\text { up } \\
\text { (mo) }\end{array}$ \\
\hline 18/F/48 & PERM & $\begin{array}{l}\text { GlyRa1/ } \\
\text { GAD655 } \\
(0.04 \\
\text { nmol/L) }\end{array}$ & NA & NA & $+($ Yes $)$ & $+(\mathrm{No})$ & ND & & $3 / 2$ & 1 \\
\hline $\begin{array}{l}19 / \mathrm{M} / \\
42\end{array}$ & Stiff limb & GlyRa1 & NA & $\begin{array}{l}\text { Exaggerated } \\
\text { acoustic } \\
\text { startle/ } \\
\text { exaggerated } \\
\text { exteroceptive } \\
\text { response }\end{array}$ & $+($ Yes $)$ & ND & ND & $\begin{array}{l}\text { Ritux } \\
\text { (No) }\end{array}$ & $3 / 2$ & 11 \\
\hline $\begin{array}{l}20 / \mathrm{M} / \\
10\end{array}$ & Stiff trunk & GlyRa1 & Negative & $\begin{array}{l}\text { Exaggerated } \\
\text { exteroceptive } \\
\text { response }\end{array}$ & ND & $+(\mathrm{No})$ & $+($ Yes $)$ & $\begin{array}{l}\text { Ritux } \\
\text { (Yes) }^{f}\end{array}$ & $5 / 2$ & 30 \\
\hline
\end{tabular}

Abbreviations: AZA = azathioprine; F = female; GAD65 = glutamic acid decarboxylase 65 kDa isoform; GlyRa1 = glycine receptor alpha-1 subunit; IgG = immunoglobulin G; $M=$ male; $m$ RS = modified Rankin Scale; Myco = mycophenolate mofetil; NA = not available; $N D=$ not done; PERM = progressive encephalomyelitis with rigidity and myoclonus; PLEX = plasma exchange; Ritux = rituximab; SPS = stiff-person syndrome.

a Symptom distribution in 5 patients with stiff limb was bilateral lower extremities (3), right upper and left lower extremities (1), and bilateral upper and lower extremities (1). Other findings were: axial and limb muscle spasms (15), hyperekplexia (7), myoclonus (7), and seizures (2, both had PERM).

${ }^{\mathrm{b}}$ Improved with administration of benzodiazepines but was not treated with immunotherapy.

c Deceased.

d Underwent testing while taking benzodiazepines and baclofen.

e Very responsive to steroids/IVIg initially but subsequently relapsed and was refractory to immunotherapy.

${ }^{\mathrm{f}}$ Remitted after rituximab treatment, but relapsed if treatment interval was longer than 6 months.

cortical grey matter in the context of status epilepticus (1) and diffuse, subtle pachymeningeal enhancement (1).

\section{Treatments and outcomes}

Treatment response and outcome information were available for 19 of 20 patients. Eighteen patients received immunotherapy and 1 patient received only benzodiazepines (table). Objective improvements were noted in 16 of 18 patients who received immunotherapy (89\%): 9 of 10 were treated with corticosteroids, 8 of 10 were treated with IVIg, 3 of 4 were treated with plasma exchange, and 1 patient was treated with rituximab. Seven patients relapsed on treatment cessation and improved again on treatment resumption. Treatment-sparing maintenance strategies were successful in 4 of 7 patients (rituximab $[2 / 3]$, azathioprine $[1 / 1]$, and mycophenolate $[1 / 3])$. The median modified Rankin score was 3 at presentation (range, 2-4) and 1 at last follow-up (range, 0-6; median follow-up, 9 months [range 1-120]). Both patients who died had PERM.

\section{Discussion}

GlyR $\alpha 1-\operatorname{IgG}$, when detected by cell-binding assay in SPS spectrum disorders, is confirmatory of that diagnosis and is indicative of a likely immunotherapy response. However, the positivity rate among a large and diverse nonautoimmune neurologic control cohort was $4 \%$. Caution is advised when interpreting results from this test beyond the SPS spectrum context, particularly in those with coexisting systemic autoimmune diseases. CSF testing might improve specificity but alone would not be a reliable alternative to serum, given the low CSF detection rate of GlyRa1-IgG in our cohort. Insights into antibody specificity may be gained in dubious cases by evaluating the serum for GlyRa1-modulating antibody.

In our experience, GlyRa1-IgG from patients with SPS spectrum (but not from healthy controls or a functional patient) caused antigenic endocytosis (modulation). There is precedence for a similar diagnostic approach in myasthenia gravis. Acetylcholine receptor (AChR) modulating antibody can be used to distinguish between patients with myasthenia gravis and those without myasthenia gravis who are $\mathrm{AChR}$ binding antibody positive. ${ }^{10}$ In addition, patients with $\mathrm{IgG}$ that robustly modulates $\mathrm{AChR}$ ( $80 \%$ antigen loss or more) commonly have thymoma. ${ }^{6}$ GlyR $\alpha 1$ is abundant in the retina and cerebrum, as well as brainstem and spinal cord. ${ }^{11}$ Vision loss, epilepsy, and demyelinating disease presentations have been reported as occasional accompaniments of GlyRa1-IgG, although their significance is less certain than when the antibody is encountered in SPS spectrum disorders. ${ }^{1,3,5}$

Limitations to our study include the lack of availability of nonSPS spectrum neurologic patients with GlyRa1 binding antibody positivity, aside from the patient with a functional neurologic diagnosis. Also, we did not evaluate other known pathogenic effects of GlyRa1-IgG (such as complement activation) as diagnostic biomarkers. 
The SPS spectrum we encountered is similar to that previously reported. ${ }^{1-3,5,12}$ This included patients with PERM most commonly, but also anatomically limited disease, classic SPS, and childhood-onset disease. We also noted psychiatric symptoms to be very common comparable with those encountered among patients with SPS generally. ${ }^{13}$ Oncological accompaniments were also largely consistent with previous reports (lymphoma and thymoma). ${ }^{1,14}$ Other neoplasms reported in single patients include small-cell carcinoma, chronic lymphocytic leukemia, and breast adenocarcinoma. ${ }^{15-17}$ Affected women should also be screened for ovarian adenocarcinoma (we encountered 1 case). Although coexisting GAD65 antibody was encountered in $30 \%$, none had coexisting amphiphysin autoimmunity, a rarer cause of SPS spectrum disorders. ${ }^{13}$

Robust responses to diverse immunotherapies were common among GlyRa1-IgG SPS spectrum patients as were relapses when treatments were discontinued. The immunotherapy response rate in this cohort (89\%) appears higher than that encountered among patients with SPS in general (40\%), ${ }^{13}$ although a chronic disease course is typical. Attempts to transition patients from infusion-based treatments requiring frequent administration (steroids, IVIg, and plasma exchange) to oral immune suppressants (such as mycophenolate mofetil) were not always successful. Given that GlyRa1-IgG is known to be an effector of receptor downregulation and complements cascade activation, ${ }^{1}$ long-acting B lymphocyte-depleting infusion treatments (e.g., rituximab) may permit remission maintenance for relapsing disease in some patients.

GlyR $\alpha 1-\operatorname{IgG}$ predicts immunotherapy responsiveness in patients with SPS spectrum. Glycine receptor modulating antibody is helpful to confirm the diagnosis when a falsepositive result is suspected.

\section{Author contributions}

S.R.H. and A.S.L.-C.: data collection, analysis, and interpretation and drafting of the manuscript. J.H.B., J.Y.M., A.H., E.B., V.A.L., and S.J.P.: data collection, analysis, and critical revision of the manuscript. A.M.: study concept and design; data collection, analysis, and interpretation; drafting and critical revision of the manuscript; and study supervision.

\section{Acknowledgment}

The authors thank the Center for Individualized Medicine and Department of Laboratory Medicine and Pathology, Mayo Clinic, Rochester, Minnesota for funding; Patrick Waters, PhD (Oxford University) for providing the GlyRal plasmid; and Jim Checkel, Jim Thoreson, and Larry Witt for their excellent technical support.

\section{Study funding}

This study was supported by the Mayo Clinic Center for Individualized Medicine.

\section{Disclosure}

S.R. Hinson and A.J. Lopez-Chiriboga report no disclosures. J.H. Bower received research support from AbbVie and the Parkinson Disease Foundation. J.Y. Matsumoto reports no disclosures. A. Hassan serves on the editorial board of Parkinsonism and Related Disorders and consulted for Bioblast Pharma. E. Basal reports no disclosures. V.A. Lennon holds a patent for and receives royalties from RSR/Kronus for sale of aquaporin-4 antibody testing kits and for commercial aquaporin-4 autoantibody testing performed outside Mayo Clinic; receives research support from the $\mathrm{NIH}$ and has a potential financial interest in "Aquaporin-4 as an aid for cancer diagnosis." S.J. Pittock and Mayo Clinic have a financial interest in patents that relate to functional AQP4/NMO-IgG assays and NMO IgG as a cancer marker. S.J. Pittock consulted for Alexion and MedImmune (compensation paid directly to Mayo Clinic) and received research support form Grifols, MedImmune, Alexion, and the NIH. A. McKeon has patents pending for GFAB and MAP1B as markers of neurologic autoimmunity and paraneoplastic disorders; consulted for Grifols, MedImmune, and EUROIMMUM; and received research support from MedImmune and EUROIMMUM. Go to Neurology.org/NN for full disclosure forms.

Received October 30, 2017. Accepted in final form December 5, 2017.

\section{References}

1. Carvajal-Gonzalez A, Leite MI, Waters P, et al. Glycine receptor antibodies in PERM and related syndromes: characteristics, clinical features and outcomes. Brain 2014; 137:2178-2192.

2. Hutchinson M, Waters $\mathrm{P}, \mathrm{McHugh} J$, et al. Progressive encephalomyelitis, rigidity, and myoclonus: a novel glycine receptor antibody. Neurology 2008;71:1291-1292.

3. McKeon A, Martinez-Hernandez E, Lancaster E, et al. Glycine receptor autoimmune spectrum with stiff-man syndrome phenotype. JAMA Neurol 2013;70:44-50.

4. Martinez-Hernandez E, Arino H, McKeon A, et al. Clinical and immunologic investigations in patients with stiff-person spectrum disorder. JAMA Neurol 2016;73: 714-720.

5. Martinez-Hernandez E, Sepulveda M, Rostasy K, et al. Antibodies to aquaporin 4, myelin-oligodendrocyte glycoprotein, and the glycine receptor alphal subunit in patients with isolated optic neuritis. JAMA Neurol 2015;72:187-193.

6. Howard FM Jr, Lennon VA, Finley J, Matsumoto J, Elveback LR. Clinical correlations of antibodies that bind, block, or modulate human acetylcholine receptors in myasthenia gravis. Ann N Y Acad Sci 1987;505:526-538.

7. Hinson SR, Pittock SJ, Lucchinetti CF, et al. Pathogenic potential of IgG binding to water channel extracellular domain in neuromyelitis optica. Neurology 2007;69: 2221-2231

8. Hughes EG, Peng X, Gleichman AJ, et al. Cellular and synaptic mechanisms of antiNMDA receptor encephalitis. J Neurosci 2010;30:5866-5875.

9. Czarnecki K, Thompson JM, Seime R, Geda YE, Duffy JR, Ahlskog JE. Functional movement disorders: successful treatment with a physical therapy rehabilitation protocol. Parkinsonism Relat Disord 2012;18:247-251.

10. Lozier BK, Haven TR, Astill ME, Hill HR. Detection of acetylcholine receptor modulating antibodies by flow cytometry. Am J Clin Pathol 2015;143:186-192; quiz 305.

11. Lynch JW. Native glycine receptor subtypes and their physiological roles. Neuropharmacology 2009;56:303-309.

12. Clardy SL, Lennon VA, Dalmau J, et al. Childhood onset of stiff-man syndrome. JAMA Neurol 2013;70:1531-1536.

13. McKeon A, Robinson MT, McEvoy KM, et al. Stiff-man syndrome and variants: clinical course, treatments, and outcomes. Arch Neurol 2012;69:230-238.

14. Zekeridou A, McKeon A, Lennon VA. Frequency of synaptic autoantibody accompaniments and neurological manifestations of thymoma. JAMA Neurol 2016;73: 853-859.

15. Kyskan R, Chapman K, Mattman A, Sin D. Antiglycine receptor antibody and encephalomyelitis with rigidity and myoclonus (PERM) related to small cell lung cancer. BMJ Case Rep 2013;2013.

16. Derksen A, Stettner M, Stocker W, Seitz RJ. Antiglycine receptor-related stiff limb syndrome in a patient with chronic lymphocytic leukaemia. BMJ Case Rep 2013;2013.

17. De Blauwe SN, Santens P, Vanopdenbosch LJ. Anti-glycine receptor antibody mediated progressive encephalomyelitis with rigidity and myoclonus associated with breast cancer. Case Rep Neurol Med 2013;2013:589154. 


\section{Neurology \\ Neuroimmunology \& Neuroinflammation}

\section{Glycine receptor modulating antibody predicting treatable stiff-person spectrum disorders}

Shannon R. Hinson, A. Sebastian Lopez-Chiriboga, James H. Bower, et al.

Neurol Neuroimmunol Neuroinflamm 2018;5;

DOI 10.1212/NXI.0000000000000438

This information is current as of January 24, 2018

\section{Updated Information \& Services}

References

Citations

Subspecialty Collections

Permissions \& Licensing

Reprints including high resolution figures, can be found at: http://nn.neurology.org/content/5/2/e438.full.html

This article cites 15 articles, 1 of which you can access for free at: http://nn.neurology.org/content/5/2/e438.full.html\#\#ref-list-1

This article has been cited by 1 HighWire-hosted articles: http://nn.neurology.org/content/5/2/e438.full.html\#\#otherarticles

This article, along with others on similar topics, appears in the following collection(s):

Autoimmune diseases

http://nn.neurology.org//cgi/collection/autoimmune_diseases Stiff person syndrome

http://nn.neurology.org//cgi/collection/stiff_person_syndrome

Information about reproducing this article in parts (figures,tables) or in its entirety can be found online at:

http://nn.neurology.org/misc/about.xhtml\#permissions

Information about ordering reprints can be found online:

http://nn.neurology.org/misc/addir.xhtml\#reprintsus

Neurol Neuroimmunol Neuroinflamm is an official journal of the American Academy of Neurology.

Published since April 2014, it is an open-access, online-only, continuous publication journal. Copyright

Copyright $\odot 2018$ The Author(s). Published by Wolters Kluwer Health, Inc. on behalf of the American

Academy of Neurology.. All rights reserved. Online ISSN: 2332-7812.

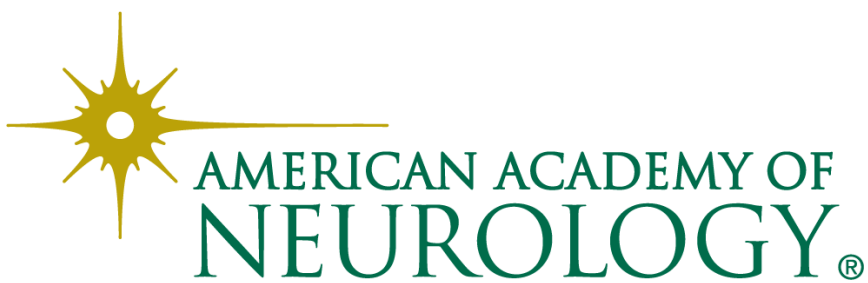

